\title{
Research and Analysis on Practical Training and Practice of Animation Design and Production Major Students
}

\author{
Luo lingxin \\ Nanchang Institute of Technology\&inform nanchang 330099, China
}

\begin{abstract}
In teaching process, the teaching characteristics and teaching objectives of animation design and production should be fully understood so as to better combine classroom content and practice together. In animation design and production major personnel training process, students should not only get classroom education, but as far as possible study in the way of practice teaching. The following describes the shortcomings of current practical teaching and how to avoid such deficiencies for better practice teaching. So the students may better understand animation design and production and gain learning interest in animation design and production.

Keywords: Animation design; Animation production; Practical training and practice; Research and analysis

In continuous development, animation design is a capital-intensive and talent-intensive new enterprise. According to the current development situation, it has a very good development prospect. China's past animation industry development was relatively slow, but this did not affect the development of the animation industry. From the development of animation industry, the consumer groups of animation industry are now in a wide range and the market demand for animation is also more. It will have a longer development cycle in the future development process. Recent development of animation industry has shown more and more attention, while the state also has some relevant policies to show the support of animation industry. The continuous development of animation industry makes more and more people find the good development prospects of animation industry. It can be seen that animation industry does have a great breakthrough. Now many animation companies begin to innovate and develop and improve the development standards, so the quality of some animation works is also rising. In animation industry's continuous development process, there are many developmental problems, such as animation industry is often in short supply and talent demand in animation is also rising. Many animation companies have the phenomenon of talent shortage. Talent shortage will not only affect the production and quality of animation industry's products, but also affect the development prospects of animation industry.
\end{abstract}

\section{Problems in animation major practical teaching}

Although China's animation industry has rapid development in recent years, according to the current development situation, there are still many deficiencies, which will be analyzed in the following points:

In animation design and production major, practice is too little which is far less than the requirements.According to the current teaching situation, universities generally pay more attention to theoretical teaching and make students learn and practice in classroom, which is not conducive to animation industry talent training, because animation industry needs talents with practical experience, who can understand enterprise work procedure and can complete the production alone. In the teaching of animation major in our country, students cannot complete the process of making a work on their own. Once the students leave the classroom, they do not know how to start the animation. This leads to the students' confusion after graduation. They do not understand what is 
suitable for them and cannot devote into the animation industry. Students lose their direction when getting into society and are not competitive in the society.

Schools' assessments on students only focus on theoretical knowledge and lack of practical ability assessment.In the process of learning, students tend to learn according to the teachers' teaching methods and put too much emphasis on the theoretical knowledge in books. Once left the textbooks, students do not know what to do, and in the course of learning they have not realized the importance of animation major practical teaching for the future animation industry development. In the course of practical teaching, students are too dependent on teachers and cannot learn and search on their own. A large part of the students do not pay attention to practical lessons and they think their theoretical knowledge is very solid, so their practical ability is certainly very good. In practical teaching, many schools have not built practical knowledge ability assessment program, and student's performance is based on their theoretical knowledge grasping situation and usual performance. With no practical ability assessment program, students certainly will not pay attention to practice, which is not conducive to the development of students and will not improve the enthusiasm of students on practice.

The schools' practice class arrangement is unreasonable.Most of the practice projects in schools are centered on a course. Many teachers tend to pay attention to their own courses. They also arrange the content of their own courses for the practice of their own teaching. This teaching method cannot make a good combination of curriculum and practice which does not meet the requirements. This is not conducive to the understanding of students and cannot make students apply the learned knowledge to practical process. In the course of practice, they do not know how to analyze and solve the problems based on their own knowledge.

Animation major students lack teamwork and good communication skills. Now students like to act alone more in the process of learning. They seldom communicate with others in learning and depend on themselves in all aspects. But according to the development of animation industry, it is impossible to complete a work only by a person's power, and there is a mutual help team behind each animation product. In order to complete a work, students must work with others and a team's joint efforts will complete very good work.

\section{Animation design and production major design and analysis}

In the teaching process of school animation design and production major, carry out practical teaching according to the effect of usual tasks, hands-on practical ability, and graduation works, etc. In teaching process, teachers should timely check students' basic knowledge mastery. In the process of teaching, teachers cannot ignore practical teaching.

\section{Practical teaching gives great help to students' learning.}

(1) Such teaching method can find the problems in teaching process in time, and timely find a solution to correct them, and avoid such problems in future teaching.

(2) Students should strengthen the understanding of theoretical knowledge after learning for consolidation and cannot put aside after learning.

(3) Practical teaching can stimulate students' self-learning and creative ability in the practice.

(4) It is good for students' team cooperation ability, so the students' cooperation and communication skills will be improved.

(5) It is conducive to improving the practical ability of students in order to be better recognized by the enterprises in the future. 


\section{The design and analysis of practical teaching}

(1) In practical teaching, animation design and production major teaching methods have been greatly changed. With more and more attention on animation industry, the development trend of China's animation major education mechanism is also more and more obvious. According to the survey, the educational institutions which can train professionals who can master animation production skills are very few, which is far less than the demand for animation industry. This is not conducive to the rapid development of China's animation industry. In order to better solve this problem, every university should base on the market and build relevant practical courses according to the social needs of animation production talents, continue changing teaching methods, and strive to cultivate more adaptable animation industry application talents. The specific reform methods are as follows: according to the social demand for animation talents, traditional teaching methods certainly do not work. We must change the traditional teaching methods. The current teaching methods should combine theoretical teaching and practice teaching together, and should not only pay attention to a certain point. Use more multimedia technology so that students can have more intuitive learning and improve students' enthusiasm for learning so that the classroom atmosphere is more active. In school, teachers should allow students to participate in practice as much as possible and provide students with practical opportunities. Guide students to actively participate in practice rather than cope with teachers to participate in practice. Just practice in schools do not meet the requirements, so the school should more relate to some animation businesses to provide more opportunities for students practice. Students continue to find their own problems and correct them in the process of social practice.

(2) It ensures the teaching methods for animation design and production major. To make students more intuitively learn knowledge, it is not enough for just teachers' lectures. Teachers in the course of practical teaching should monitor the students' completion of the work and do the duty. For colleges and universities, in order to achieve social demand for talents, the requirements of teachers should continue to be improved and the school should not only pay attention to student learning, but also provide teachers with better learning opportunities. Only when the teacher's teaching quality improves can they educate more professional talents. Teachers can participate in the construction of training base which can also allow teachers to enter the enterprise learning project and complete the process. In the process of assessment, relevant practice assessment system is established and the assessment of theoretical knowledge can no longer be the focus.

\section{Recommendations for strengthening practical training}

Teaching curriculum setting and time arrangement .In order to cultivate students' hands-on ability in animation design and production, allow students to study classroom content more intuitively so that students can apply the learned theoretical knowledge to hands-on process. In accordance with this practical class's hands-on teaching methods, students can better grasp the basic knowledge and apply the knowledge points to practice. Find their own deficiencies in the practice and improve their own animation design and production understanding. What is time arrangement? It is based on student's grade and their mastering of theoretical knowledge, and in time conditions permission, we should strengthen practical guidance so that students may better get into practice. Practical teaching has a great influence on students' learning. In the process of teaching, we should strengthen the importance of practical courses, guide students to participate in practice, and find 
problems and discuss with students in practice in order to find a solution, and finally improve the enthusiasm of students to learn.

Practical projects source .Major colleges and universities should have more cooperation with large enterprises and introduce more exercise projects so that students can get better exercise in the process of learning, or let the students go into the enterprise. In enterprise practice, students can learn experience in the process of internship and apply the learned knowledge to the practice. Schools can also pick up some enterprises tasks and ask the teachers and students to complete, which can also improve the cooperation ability and communication skills of students, so that the relationship between teachers and students would be more close.

Improve students' professional quality.The construction of training courses makes continuous practice opportunities for students, which not only develops students' professional and technical ability, but more importantly enables students to learn experience in practice and makes preparation for the future work. The practical training and practice course is designed to help students deal with the relationship between themselves and their colleagues in work after graduation and learn how to complete work in cooperation process.

Make rigorous training in accordance with the requirements .Students in practical training and practice cannot relax because this is not a real job, and teachers should strictly require students to complete the training in accordance with the standards of training. Let students take this as their own work. They should pay attention to the course and do their best. Teachers should correct their own mentality in supervision students, and complete the training in accordance with the requirements of the work and prepare students for the future work.

Participate in skill contest.Students are encouraged to participate actively in school and social skill competitions to cultivate students' innovative ability and teamwork ability. It is not enough to practice just in class. Although practical courses can make students learn experience, students learn much more in contests than what they have learned in the classroom. Skill competition can help them learn very important experience, and can make students to a large extent understand their own deficiencies through the participation. Skills contests can enhance students' self-learning ability in the practice and produce big interest in animation design and production major learning.

According to the above study, it is found that the process of animation design and production major talent training should face the society and keep up with the pace of social development. According to the needs of current social enterprises for talents, well-trained and efficient personnel are cultivated with plans. According to the situation, colleges should provide practical opportunities for students to practice as much as possible, let students practice in practice, and improve the quality of teachers to prepare students for good jobs in advance. According to the current development of animation industry, change the teaching methods, develop suitable teaching programs for the current development, cultivate animation industry talents, and promote the development of China's animation industry.

\section{References}

[1] Wang Yueming. Study on practical teaching of animation design and production in higher vocational education [J]. Information and Computer (Theoretical Edition), 2015, (13): 165-166.

[2] Xu Qianyan. Animation design and production major training practice and practice research [J]. Science and Technology Innovation and Application, 2013, (04): 268. 
[3] Dai Bing. Artistic design and production major training scheme research in secondary vocational education [J]. Journal of Hebei Normal University (Natural Science Edition), 2010.

[4] Zhang Cuihong. Animation design and production major training practice research [J]. Vocational Education Research, 2009, (07): 143-145. 